\title{
Effect of Prophylactic Physical Activities on Reducing Lymphedema among Women Post Mastectomy
}

\author{
Jehan Sayyed Ali ${ }^{1}$, Lobna Mohamed Gamal ${ }^{2}$ Tawheda Mohamed Khalifa El-saidy ${ }^{3}$ \\ ${ }^{1,2}$ Assistant Professor of Medical Surgical Nursing Department, Faculty of Nursing, Minia University, Egypt.
}

\section{Assistant Professor of Geriatric Nursing Department, Faculty of Nursing Menoufia University, Egypt}

\begin{abstract}
:
Background: Lymphedema is the build-up of lymph fluid in the tissues just under the skin. Lymphedema following mastectomy as a treatment for breast cancer is a major concern for most women who experience it. Physical activities are very helpful for lymphedema control. Aim: To evaluate the effect of prophylactic physical activities on reducing lymphedema among women post-mastectomy. Subjects \& Method: Design: A Quasiexperimental design was utilized. Setting: This study was carried out in Minia oncology center- outpatient and inpatient surgical department. Affiliated by Secretariat of Specialized Medical Centres, at Minia Governorate, Egypt. Subjects: Included a total of 200 women have had a mastectomy. Tools: Five tools were used. 1) structured questionnaire; 2) scale for pitting edema measurement; 3) scale for lymphedema stage assessment; 4) international physical activity Questionnaire; 5) observational checklist for Physical Activities performance. Results: The mean age of the sample was 58.9 years old and $52.5 \%$ of them were elderly women. During the first assessment, more than eighty percent of the sample complained from a stage 1 lymphedema. However, there was a significant reduction in this percentage among the study group during post-test. Likewise, there was a statistically significant difference between the groups regarding the lymphedema time and stage of development during the first assessment, after 6 weeks and 16 weeks $(\mathrm{P}<0.001 *)$. Moreover, $49.0 \%$ of the study group compared to $29.0 \%$ of the control group had a moderate level of physical activity during the post-test. This indicated an increase in the level of a total pattern of physical activity between the two groups during the post-test. Conclusion: Prophylactic physical activities can reduce lymphedema associated symptoms. Also, the study group had a better level of physical activities than the control group. Recommendations: Early detection and nursing interventions have been gradually advocated to prevent lymphedema progression. So, the prophylactic physical activities are essential measures post-mastectomy to reduce lymphedema.
\end{abstract}

Keywords: Lymphedema, Prophylactic, Physical activities, Mastectomy.

DOI: $10.7176 / \mathrm{JHMN} / 61-10$

Publication date: April $30^{\text {th }} 2019$

\section{$\underline{\text { Introduction }}$}

Breast cancer $(\mathrm{BC})$ is the second most common cancer in the world. It is associated with a high level of morbidity and mortality in developing countries of malignant disease in women (American cancer society, 2011; Ferlay et al., 2015). World Health Organization (WHO), 2015 reported that there was a sharp rise in BC worldwide in 2012; 1.7 million women were diagnosed with BC. The incidence has increased by more than $20 \%$, while mortality has increased by $14 \%$. It currently accounts for more than 8 million deaths according to the World Cancer Report 2014 (Siegel et al., 2014; Angahar, 2017). Recent research stated that over a million new cases of breast cancer are diagnosed every year. Additionally, both mortality and burden of BC are high (Angahar, 2017). According to the National Cancer Registry Program of Egypt, 2012 BC is the most common cancer among Egyptian women and it carries an disapproving prognosis with $29 \%$ mortality and 3.7:1 incidence to mortality; And 34\% of Egyptian women have breast cancer 2017(WHO, 2018). BC is influenced by multiple risk factors such as increasing in age, family history, socioeconomic status, lifestyle, reproductive history, radiation, hormone therapy, oral contraceptives, lower levels of physical activity, higher body mass index and alcohol intake (International Agency for Research on Cancer, 2012; Variawa, 2016; American Institute for cancer research, 2017).

Lymphedema is a major problem. It is an abnormal regional accumulation of protein-rich fluid in the interstitial space that can result in oedema formation and chronic inflammation (Lee et al., 2013; Miller \& Linda, 2014). It is one of the most troubling complications that can develop after cancer surgery when the number of lymph nodes removed as partial segmental mastectomy, modified radical mastectomy and radical mastectomy (Bevilacqua et al., 2012; Miller \& Linda, 2014). It is more common in the arm or hand on the same side of the breast surgery. 
Furthermore, it can affect the breast, chest, axillary areas, legs, and genital area (DiSipio et al., 2013; Australia \& New Zealand Society of Vascular Surgeons, 2018). As regards to the initial symptoms of lymphedema, it includes pain, heavy sensation or an aching discomfort, burning sensation, swelling, fatigue with use, and numbness or tingling (Mehrara, 2018).

Lymphedema can be classified into primary and secondary types. Primary lymphedema progresses as a result of the congenital absence of lymphatic system components or their primary defects. Secondary type is a most common type results from disease processes, surgical intervention, radiotherapy, trauma, inflammation, and mass compression (International Society of Lymphology, 2013). The prevalence of secondary lymphoedema in breast cancer women has been reported to be between $6 \%$ and $80 \%$ (Siegel et al., 2012). According to the previous studies, the cumulative incidence of lymphedema was $41.1 \%$. Besides that, women undergoing axillary radiotherapy, who developed a seroma, obese, underwent chemotherapy infusion in the affected limb and with progressive disease had a higher risk of lymphedema (Clark \& Sitzia, 2005; Pereira et al., 2017).

There are different risk factors that can increase the risk for lymphedema incidence after surgery. These factors comprised the stage of a tumour, its location, recurrence of a tumour or spread to the lymph nodes, extent of lymph node dissection, wound infection, scar formation, fibrosis, radiation therapy, axillary lymph node dissection, trauma to the affected limb, high BMI $>3 \mathrm{~kg} / \mathrm{m} 2$, hypertension, elderly women, poor mobility, compromised circulation, inability to control early signs of lymphedema at the sub-clinical level, and previous cellulitis (Paskett et al., 2012; Tiwari et al., 2013).

As regards to the types of lymphedema, it included mild, moderate and severe lymphedema. As regards to mild type, it can happen within a few days after surgery and usually lasts a short time. Moderate lymphedema considered the more painful type and can occur about four to six weeks after surgery; while, the severe lymphedema is the most common type. It is painless and may slowly develop eighteen to twenty-four months or more after surgery (Bar et al., 2010).

Lymphedema progresses through four stages. The first stage called zero or the sub-clinical stage. It involved no visible signs of lymphedema. However, changes in sensation, such as a mild tingling, or slight limb heaviness may be noted. This stage can exist for months or years. The stage I is spontaneously reversible. The limb and the adjacent part of the trunk appear mildly swollen as protein-rich fluid starts to accumulate. After pressing the skin results in temporary small pitting oedema. This stage is reversible with treatment as the skin and tissues are not permanently damaged. Swelling reduces at night. Usually, upon waking in the morning, the affected area is almost normal in size (Kaviani et al., 2013).

Stage II of lymphedema is irreversible and the affected limb is more swollen. Swelling does not reduce at night. Pressing on the skin do not leave a pit and inflammation and fibrosis take place. This stage can be managed but tissue damage is irreversible. Regarding stage III, it is severe and irreversible. This is the most advanced stage but is relatively rare. It rarely occurs in patients with breast cancer. The interventions in the early stages can prevent the onset of severe clinical features. Therefore, it is important to early diagnose and treat the lymphedema at the sub-clinical stage (Norman et al., 2009; Malin et al., 2014).

Health care personnel and women must be aware of the prevention and early treatment of lymphedema (Safwat et al., 2017). According to Cheifetz \& Haley, (2013) the prevention and lifestyle modifications such as exercise regularly, receive lymphedema education before surgery, and perform preventive self-care activities can lower the incidence of lymphedema. Exercise is an effective treatment. It can reduce intra thoracic pressure during inspiration and more respiratory effort and facilitating lymph flow and lymph clearance (Kayiran et al., 2017). Similarly, reduction of body fat content by exercise helps more in lymphedema management due to the swelling tendency in fat tissues (Modaral \& Lyons, 2016). Exercise training doing a treatment process to control lymphedema in BC survivors (Naghibi \& Tabrizi, 2018). It is safe and efficient for lymphedema management (Schmitz et al., 2010). Added to that, weight reduction improves compression pump efficacy and lowers body fat content that all result in lymphedema improvement (Mohler et al., 2016).

The nurses can play a vital role in the prevention of lymphedema. The aim of nurses is to rehabilitate the women at various stages of treatment during inpatient, outpatient or sanatoria treatment (Norman et al., 2009; Korpan et al., 2011). The prophylactic physical activities should begin immediately after mastectomy, at a hospital ward and should involve both the women being at risk of the lymphedema and those who already developed lymphatic 
insufficiency. The principles of lymphedema prevention should be offered by properly trained nurses (Dziura \& Grądalski 2008; Rasu et al., 2011). It is important to identify the high-risk women, advising them and demonstrating preventive exercises (National Cancer Control Programme, 2015).

\section{Significance of the Study:}

Lymphedema is a devastating disease affecting millions of women (Kayıran et al., 2017). The incidence of lymphedema increases from $13.5 \%$ in two years to $41.1 \%$ in ten years. It influences the daily activities and patient self-esteem (Kayıran et al., 2017). Lymphedema can reduce tissue healing and sometimes causes chronic pain. Also, the lymphedema limb can develop cellulitis that needs antibiotics and possible hospitalization. For these reasons, prevention of lymphedema is important to reduce these complaints (Sisman, 2012; Mehrara, 2018). Lymphedema is significantly decreased when the women are well educated about the prevention of it and exercise regularly. The education provided by nurses about the prophylactic physical activities can reduced lymphedema development (Sisman et al., 2012). Added to that, the most important prophylactic measures are appropriate hygiene, protection of the skin, and avoidance of factors that can cause the oedema or enhance its severity such as overload with physical work, overheating and injuries (Golshan et al., 2006; Pyszora et al., 2007; Korpan et al., 2011; Huang et al., 2013). So, the medical-surgical and geriatric nurses should play their role in teaching the patients about the prophylactic physical activities and follow them to reduced lymphedema.

\section{The aim of the Study:}

The current study aims to evaluate the effect of prophylactic physical activities on reducing lymphedema among women post-mastectomy.

\section{Research Hypothesis:}

1) Prophylactic physical activities will reduce the lymphedema associated symptoms among the intervention group.

2) Women who practice prophylactic physical activities are more likely to increase their level of physical activity than before the intervention.

3) The study group will have a better level of physical activities than the control group.

\section{Subjects and Method:}

\section{Research Design:}

A Quasi-experimental research design was utilized in the current study

Setting: The current study was conducted at oncology center outpatient and inpatient surgical department, Affiliated by Secretariat of Specialized Medical Centres at Minia Governorate, Egypt.

\section{Study Subjects:}

A purposive sample of 200 women has had a mastectomy recruited from an oncology center in outpatient and inpatient surgical department after their acceptance to participate in the study. The researchers selected women who will be undergone simple mastectomy and modified radical mastectomy during the preoperative time and start the intervention postoperative. They were assigned in the current study, they classified into two equal groups (100 for the study group and 100 for the control group). The women were enrolled based on the inclusion and exclusion criteria.

The sample size: the sample sizes were calculated according to the following equation: $n=t^{2} \times p(1-p) / m^{2}$

$$
\begin{aligned}
& \mathbf{n}=\text { required sample size } \\
& \mathbf{t}=\text { confidence level at } 95 \%(\text { standard value of } 1.96) \\
& \mathbf{p}=\text { estimated prevalence of risk }(0.07)
\end{aligned}
$$


$\mathbf{m}=$ margin of error at $5 \%$ (standard value of 0.05$)$

$\mathrm{n}=(1.96)^{2} \times 0.07(1-0.07) /(0.05)^{2}=100$ women for each group.

Inclusion Criteria: women who had undergone simple mastectomy and modified radical mastectomy (pre and immediate post-mastectomy, age $\geq 18$ years, agree to share in the study and able to provide written informed consent.

Exclusion Criteria: Presence of infection in the affected arm.

Tools for Data Collection: five tools were applied to collect data for the study.

First Tool: Structured Questionnaire: It was designed by the researchers, by interviewing. It contained three parts:

A. Socio-Demographic Characteristics such as age, residence, marital status, education, and working condition.

B. Medical Data: Which included questions about the patient's complaints, past and present medical histories, family history of cancer, and risk factors that increases the risk for lymphedema such as radiotherapy, age $>65$ years, lifting heavy objects, wear too tight underwear, take injection in the affected arm, wear accessories in the affected arm, exposure to sunlight, exposure to heat, and obesity. Lymphedema associated symptoms such as pain, arm heaviness, discomfort, in ability to move the arm, axillary oedema and tenderness in the breast area.

C. Anthropometric measures: This included weight, height, and body mass index (BMI). The BMI is estimated by dividing weight in kilogram divided by squared height in meters [BMI $=$ weight $(\mathrm{kg}) /$ height $(\mathrm{m})^{2}$ ]. A BMI of less than 18.5 is underweight, a BMI from $18.50-24.99$ is normal while a BMI from $25-29.9$ considered overweight and $\geq 30$ is considered obese (WHO, 2004).

2. Scale for Pitting Edema Measurement: It includes the 1+ (mild, slight pitting, not noticeable, 2+ (moderate pitting, subsides rapidly, 3+ (deep pitting, remains for short time ) and 4+ (very deep and remains for a long time). Brodovicz et al., (2009)

3. Scale for Lymphedema Stage: The scale contains three stages:

Stage 1: is the mildest form. The limb is usually normal size in the morning but swells during the day. The tissue will hold an indentation when we press on it.

Stage 2: is moderate. It's characterized by an irreversible form of swelling in which the limb tissue feels spongy to the touch.

Stage 3: is the most severe stage. It involves an irreversible form of edema in which the affected limb hardens and becomes very large. (International Society of Lymphology, 2013).

4. International Physical Activity Questionnaire (IPAQ): used to obtain internationally comparable data on health-related physical activity. It included five parts. The job related physical activity, transportation, housework activities, recreational activities, and time spent sitting (Craig et al., 2003). The categorical levels include three levels of physical activity. Category 1 (Low): This is the lowest level of physical activity. Those individuals who not meet criteria for categories 2 or 3 are considered low/inactive. Category 2 (Moderate): it includes any one of 3 or more days of vigorous activity of at least 20 minutes per day 5 or more days of moderate-intensity activity or walking of at least 30 minutes, 5 or more days of any combination of walking, moderate-intensity or vigorous intensity activities. Category 3 (High): it includes vigorous-intensity activity on at least 3 days, 7 or more days of any combination of walking, moderate-intensity or vigorous intensity activities.

5. Observational Checklist for Physical Activities practice: This observational checklist is developed by the researchers to assess the practice of the participants related to the exercises. It concerns arm and shoulder exercises before and after mastectomy. As shoulder flexion with hand, shoulder abduction with hand, shoulder depression, snow angel, "T" and "Y" stretch, butterfly wings, forward pinky slide, sideways pinky slide, and median nerve glide. The scoring system is divided into two parts. Each one contains a number of statements about arm and shoulder exercise physical activity and are scored as complete done $=5$, incomplete $=2.5$, not done $=0$. 
Reliability and Validity of the Tools: Validity: The developed tools content were submitted to a panel of five experts in the field of medical-surgical nursing, community health nursing and oncology medicine to test the content validity. Modifications are carried out according to the panel judgment on the clarity of the sentences and appropriateness of the content. Reliability: the tools were designed in final format and tested for reliability by using Cronbach alpha coefficients; 0.79, 0.85, 0.94, 0.88 for tool 2,3,4,5 (Sun et al., 2007).

Pilot Study: A pilot study was carried out on approximately $10 \%$ of the study sample in a selected setting to evaluate the applicability, feasibility and clarity of the tools and to estimate the time needed for filling the tool. The pilot study sample was included in the study sample because no modification is done in the study tools. The average length of time needed to complete the structured interview questionnaire; it is approximately 60 minutes with each participant. The sample included in the pilot study is excluded from the study sample.

\section{Fieldwork:}

Before conducting the study, permission had been obtained from administrative personnel of the oncology center outpatient and inpatient surgical department, oncology center Affiliated by Secretariat of Specialized Medical Centres at Minia Governorate, Egypt.

and informed consent of the participants who were participated. The data collection period was for 14 months, starting from the beginning of June 2017 to April 2018. Data collection is carried out in three phases: assessment phase, implementation phase, and the evaluation phase.

\section{Assessment Phase:}

The women interviewed preoperatively during the first visit inpatient surgical department before the day of mastectomy operation. The researchers explained the aim of the study. The participants assigned into two groups. The first group (study group) consisted of 100 women. The researchers completed the questionnaire from them. Then they explained how to do exercise after mastectomy, the natural course of lymphedema, and how to prevent it. The time needed for completing the questionnaire ranged from 45 to 60 minutes for each participant. After completing the study group the researchers selected the control group (100 women).

\section{Implementation Phase:}

In this phase, all recruited women were interviewed along four sessions, one session preoperatively, three sessions after the operation. study group all women were divided into ten groups (10 women) in each group. Each session lasted from 45-60 minutes; the obtained information used as the baseline assessment (pre-test).

Before beginning the session the researchers started by measuring the weight, height, and BMI then the researcher starts training women self-drainage massage techniques to be used daily, flexibility and strength exercises and appropriate exercises after mastectomy. All exercise and any information were detailed and reinforced in a booklet that was given to the participant.

During the postoperative period immediately after the operation, exercises started on the first day and long stay in the hospital. Also, the researchers measured the degree of pain and completed the assessment sheet. Each group had three sessions after the operation. Each session took about $45-60$ mines. Asked the participated women to attend an outpatient clinic for follow-up.

Evaluation Phase: In this phase, patients were reassessed immediately after the operation, after 6 weeks and then 16 weeks after the second assessment. All women attended the follow-up sessions at the outpatient clinic to complete the questionnaire.

\section{Ethical and Administrative Considerations:}

Official permission was taken from the authoritative person in the Oncology centre, affiliated by General Secretariat of Specialized Medical Centres, The researchers introduced themselves to the women who met the inclusion criteria and informed them about the aim of the current study in order to obtain their acceptance to share in this study. Women were informed that participation in this study was voluntary and they could withdraw at any 
time without giving reasons. Written consent was obtained from them. Confidentiality and anonymity of them were assured through coding the data.

Statistical Analysis: Data were coded and transformed into a specially designed format suitable for computer feeding. All entered data were verified for any errors. Data were analyzed using statistical package for social sciences (SPSS) version 20 windows and were presented in tables and graphs. Chi-square analysis was performed. Also, the mean and standard deviations were computed. An alpha level of 0.05 was used to assess significant differences.

\section{Results:}

The study sample included 200 women at Oncology Centre, affiliated by General Secretariat of Specialized Medical Centres, at Minia Governorate, Egypt; with the mean age of the studied sample was $58.9 \pm 10.8$ years old. Table (1) illustrates the socio-demographic characteristics of the studied sample. According to the table, the mean age of the study group was $58.3 \pm 11.7$ years old, while the mean age of the control group was $59.6 \pm 9.9$ years old. More than half $(52.5 \%)$ of the participants were elderly women. Additionally, more than half of the total samples were living in rural areas (62.5\%) and $72.5 \%$ were not working. About half of the total sample (49.5\%) was married and more than one-third of the total sample were illiterate $(37.0 \%)$ compared with $(18.0 \%)$ of the sample had a university education.

Table (2) shows that the most of the reported history and health-related data in the studied sample were arthritis $(49.0 \%)$, hypertension $(44.5 \%)$, diabetes $(20.5 \%)$, modified radical mastectomy $(75 \%)$, and simple mastectomy $(25 \%)$, more than one third of studied sample had family history of cancer $(36.5 \%)$, and most of them were obese $(84.5 \%)$

Table (3) explains the characteristic of lymphedema development among the study group. It shows that during the first assessment more than eighty percent $(88.0 \%, 83.0 \%)$ of the sample complained from a stage 1 lymphedema after surgery. However, there was a significant reduction in these percentages among the study group after the implementation of the prophylactic physical activities. Also, there was a statistically significant difference between the control and study group regarding the lymphedema time, stage of development and pitting edema during the first assessment, after 6 weeks evaluation and post 16 weeks evaluation after second follow up $(\mathrm{P}<0.001 *)$.

Table (4) reveals that most of the sample suffered from lymphedema associated symptoms such as arm heaviness $(99.0 \%, 100.0 \%)$, discomfort $(84.0 \%, 100.0 \%)$ inability to move the arm $(78.0 \%, 100.0 \%)$, discomfort $(84.0 \%$, $100.0 \%)$, axillary edema, and from moderate to severe tenderness in breast area $(80.0 \%, 88.0 \%)$ during the first assessment after surgery. While in the second and third assessment there was a significant improvement and reduction in the incidence of lymphedema associated symptoms especially among the study group $\left(\mathrm{p}<0.001^{*}\right)$. The table also revealed an observed reduction of pain during the first assessment, post 6 weeks, and post 16 weeks especially among the study group. Also, there was a statistically significant difference between the groups related to the total score of pain experience $\left(\mathrm{P}<0.001^{*}\right)$.

Table (5) presents that the greatest reported risk factors that increase the risk for lymphedema among the participants were obesity $(84.5 \%)$, exposure to heat during cooking $(79.0 \%)$, exposure to sunlight $(76.5 \%)$, wear too tight underwear clothes $(63.0 \%)$, lifting heavy things $(60.5 \%)$, and age more than $65(44.0 \%)$.

Figure (1) illustrates that there was a significant reduction in the mean score of pitting oedema for the study during the first assessment, 6 weeks, and 16 weeks after surgery while the mean score of pitting oedema for the control group still high.

Table (6) confirms that about half (49.0\%) of the study group compared to only $29.0 \%$ of the control group had a moderate level of physical activity during the post-test (after 16 weeks). This indicated an increase in the level of a total pattern of physical activity for the study group with statistically significant differences between the two groups during the post-test $\left(\mathrm{P}<0.05^{*}\right)$. So, the study group had better physical activities than the control group.

Table (7) demonstrates the total mean score of exercises performed for the study group during the first assessment, post 6 weeks, and post 16 weeks after a mastectomy. The score of the patients exercises performance still good during the stage of assessment and posttest. 
Table (1): Distribution of Socio-Demographic Characteristics for the Studied Sample (n= 200)

\begin{tabular}{|c|c|c|c|}
\hline Socio-demographic Characteristics & $\begin{array}{l}\text { Study Group } \\
(\mathbf{n}=\mathbf{1 0 0})\end{array}$ & $\begin{array}{l}\text { Control Group } \\
\qquad(\mathbf{n}=\mathbf{1 0 0})\end{array}$ & $\begin{array}{r}\text { Total } \\
\mathbf{N}=\mathbf{2 0 0} \\
\end{array}$ \\
\hline Age (years): Mean \pm SD & $58.3 \pm 11.7$ & $59.6 \pm 9.9$ & $58.9 \pm 10.8$ \\
\hline$<60$ year & $48.2 \pm 6.7$ & $50.3 \pm 5.8$ & $95(47.5 \%)$ \\
\hline$\geq 60$ year & $68.4 \pm 5.2$ & $67.4 \pm 4.4$ & $105(52.5 \%)$ \\
\hline \multicolumn{4}{|l|}{ Residence: } \\
\hline Rural & 63.0 & 62.0 & $125(62.5)$ \\
\hline Urban & 37.0 & 38.0 & $75(37.5)$ \\
\hline \multicolumn{4}{|l|}{ Level of Education: } \\
\hline Illiterate & 36.0 & 38.0 & $74(37.0)$ \\
\hline Read \& Write & 25.0 & 26.0 & $51(25.5)$ \\
\hline Secondary School & 19.0 & 20.0 & $39(19.5)$ \\
\hline University & 20.0 & 16.0 & $36(18.0)$ \\
\hline \multicolumn{4}{|l|}{ Working Condition: } \\
\hline Not work & 70.0 & 75.0 & $145(72.5)$ \\
\hline Work & 30.0 & 25.0 & $55(27.5)$ \\
\hline \multicolumn{4}{|l|}{ Marital Status: } \\
\hline Single & 31.0 & 28.0 & $59(29.5)$ \\
\hline Married & 50.0 & 49.0 & $99(49.5)$ \\
\hline Divorced & 3.0 & 13.0 & $16(8.0)$ \\
\hline Widow & 16.0 & 10.0 & $26(13.0)$ \\
\hline
\end{tabular}


Table (2): History and Health Related Data for the Two Groups $(n=200)$

\begin{tabular}{|l|c|c|c|}
\hline Variables & Study Group & Control Group & Total \\
& $(\mathbf{n = 1 0 0})$ & $\mathbf{( n = 1 0 0 )}$ & $41(20.5)$ \\
\hline Diabetes & 20.0 & 21.0 & $89(44.5)$ \\
\hline Hypertension & 44.0 & 45.0 & $98(49.0)$ \\
\hline Arthritis & 50.0 & 48.0 & $150(75.0)$ \\
\hline Modified Radical Mastectomy & 80.0 & 70.0 & $50(25.0)$ \\
\hline Simple Mastectomy & 20.0 & 30.0 & $12(6.0)$ \\
\hline Previous Breast Cancer & 8.0 & 4.0 & $73(36.5)$ \\
\hline Family History of Cancer & 44.0 & $84.14 \pm 10.4$ & $160.3 \pm 3.6$ \\
\hline Weight(kg) & $84.15 \pm 10.5$ & $160.4 \pm 4.1$ & 0.4 \\
\cline { 2 - 4 } Height(cm) & $160.2 \pm 3.2$ & & $(0.0)$ \\
\hline BMI Categories: & 0.0 & 0.0 & $(4.5)$ \\
Under Weight & 4.0 & 5.0 & $22(11.0)$ \\
Normal Weight & 10.0 & 12.0 & $169(84.5)$ \\
\hline
\end{tabular}

Table (3): Characteristics for Lymphedema Development among the Participants (n=200)

\begin{tabular}{|c|c|c|c|c|c|c|c|}
\hline \multirow[t]{2}{*}{ Variables } & \multicolumn{3}{|c|}{ Study Group $(n=100)$} & \multicolumn{3}{|c|}{ Control Group $(n=100)$} & \multirow[t]{2}{*}{ P value } \\
\hline & $\begin{array}{c}\text { First } \\
\text { Assessment }\end{array}$ & $\begin{array}{c}\text { Post } \\
6 \\
6 \\
\text { Weeks }\end{array}$ & $\begin{array}{c}\text { Post } \\
16 \\
16 \\
\text { Weeks }\end{array}$ & $\begin{array}{c}\text { First } \\
\text { Assessment }\end{array}$ & $\begin{array}{c}\text { Post } \\
6 \text { Weeks }\end{array}$ & $\begin{array}{c}\text { Post } \\
16 \\
\text { Weeks }\end{array}$ & \\
\hline $\begin{array}{l}\text { Time of Lymphedema } \\
\text { by week }\end{array}$ & \multicolumn{3}{|c|}{$2.9 \pm 1.2$} & \multicolumn{3}{|c|}{$4.1 \pm 3.8$} & $\begin{array}{c}\mathrm{t}=3.4 \\
\mathrm{P}<0.001 *\end{array}$ \\
\hline Pitting Oedema Score & $2.1 \pm 0.8$ & $1.33 \pm 0.7$ & $0.5 \pm 0.6$ & $1.75 \pm 0.8$ & $1.83 \pm 0.7$ & $1.8 \pm 1.04$ & \\
\hline $\begin{array}{l}\text { Stage of } \\
\text { Lymphedema: }\end{array}$ & & $<0.001$ & & & $\mathrm{p}>0$ & & \\
\hline Stage 0 & 12.0 & 24.0 & 79.0 & 17.0 & 10.0 & 16.0 & \\
\hline Stage 2 & 88.0 & 76.0 & 21.0 & 83.0 & 65.0 & 52.0 & $X^{2}=42.4$ \\
\hline Stage 3 & $\begin{array}{l}0.0 \\
0.0\end{array}$ & $\begin{array}{l}0.0 \\
0.0\end{array}$ & $\begin{array}{l}0.0 \\
0.0\end{array}$ & $\begin{array}{l}0.0 \\
0.0\end{array}$ & $\begin{array}{l}25.0 \\
0.0\end{array}$ & $\begin{array}{l}32.0 \\
0.0\end{array}$ & $\mathrm{P}<0.001 *$ \\
\hline
\end{tabular}

Table (4): Distribution of Lymphedema Associated Symptoms among the Participants (n= 200) 


\begin{tabular}{|c|c|c|c|c|c|c|}
\hline \multirow[t]{2}{*}{$\begin{array}{l}\text { Lymphedema } \quad \text { Associated } \\
\text { Symptoms }\end{array}$} & \multicolumn{3}{|c|}{$\begin{array}{l}\text { Study Group } \\
\qquad(\mathrm{n}=\mathbf{1 0 0})\end{array}$} & \multicolumn{3}{|c|}{$\begin{array}{l}\text { Control Group } \\
(\mathbf{n}=\mathbf{1 0 0})\end{array}$} \\
\hline & $\begin{array}{c}\text { First } \\
\text { Assessment }\end{array}$ & $\begin{array}{c}\text { Post } 6 \\
\text { Weeks }\end{array}$ & $\begin{array}{l}\text { Post } 16 \\
\text { Weeks }\end{array}$ & $\begin{array}{c}\text { First } \\
\text { Assessment }\end{array}$ & $\begin{array}{c}\text { Post } 6 \\
\text { Weeks }\end{array}$ & $\begin{array}{l}\text { Post } 16 \\
\text { Weeks }\end{array}$ \\
\hline \multirow[t]{2}{*}{ Arm Heaviness } & 99.0 & 74.0 & 45.0 & 100.0 & 78.0 & 70.0 \\
\hline & \multicolumn{3}{|c|}{$\mathrm{X}^{2}=96.1 \quad \mathrm{p}<0.001$} & \multicolumn{3}{|c|}{$\mathrm{X}^{2}=7.8 \quad \mathrm{p}<0.05$} \\
\hline \multirow[t]{2}{*}{ Discomfort } & 84.0 & 67.0 & 35.0 & 100.0 & 77.0 & 75.0 \\
\hline & \multicolumn{3}{|c|}{$\mathrm{X}^{2}=46.2 \quad \mathrm{p}<0.001$} & \multicolumn{3}{|c|}{$\mathrm{X}^{2}=29.1 \quad \mathrm{p}<0.001$} \\
\hline \multirow[t]{2}{*}{ Inability to move the arm } & 78.0 & 47.0 & 29.0 & 100.0 & 76.0 & 61.0 \\
\hline & \multicolumn{3}{|c|}{$X^{2}=17.6 \quad p<0.001$} & \multicolumn{3}{|c|}{$\mathrm{X}^{2}=31.3 \quad \mathrm{p}<0.001$} \\
\hline \multirow[t]{2}{*}{ Axillary oedema } & $1.75 \pm 0.9$ & $1.24 \pm 0.9$ & $0.63 \pm 0.8$ & $1.51 \pm 0.7$ & $1.67 \pm 1.1$ & $1.68 \pm 1.1$ \\
\hline & \multicolumn{3}{|c|}{$\mathrm{p}<0.001$} & \multicolumn{3}{|c|}{$\mathrm{p}>0.05$} \\
\hline \multicolumn{7}{|l|}{ Tenderness in Breast area: } \\
\hline No & 20.0 & 28.0 & 36.0 & 12.0 & 3.0 & 2.0 \\
\hline Mild & 80.0 & 31.0 & 34.0 & 88.0 & 23.0 & 10.0 \\
\hline Moderate & 0.0 & 41.0 & 30.0 & 0.0 & 74.0 & 88.0 \\
\hline \multirow[t]{2}{*}{ Severe } & 0.0 & 0.0 & 0.0 & 0.0 & 0.0 & 0.0 \\
\hline & \multicolumn{3}{|c|}{$\mathrm{X}^{2}=55.3 \quad \mathrm{p}<0.001$} & \multicolumn{3}{|c|}{$\mathrm{X}^{2}=7.5 \quad \mathrm{p}>0.05$} \\
\hline \multirow[t]{3}{*}{ Total score for } & & & & & & \\
\hline & $20.3 \pm 3.1$ & $14.1 \pm 3.4$ & $8.3 \pm 5.2$ & $21.7 \pm 2.7$ & $18.5 \pm 2.5$ & $18.1 \pm 4.9$ \\
\hline & \multicolumn{3}{|c|}{$\mathrm{p}<0.001$} & \multicolumn{3}{|c|}{$\mathrm{p}<0.05$} \\
\hline
\end{tabular}

Table (5): Risk Factors That Can Increase the Risk for Lymphedema among the Participants (n=200)

\begin{tabular}{|l|c|c|c|}
\hline Risk Factors & Study Group & Control Group & Total \\
& $(\mathbf{n = 1 0 0 )}$ & $\mathbf{n = 1 0 0})$ & $\mathbf{N = 2 0 0}$ \\
\hline Radiotherapy & 31.0 & 30.0 & $61(30.5 \%)$ \\
\hline Age $>$ 65 years & 43.0 & 45.0 & $88(44.0 \%)$ \\
\hline Lifting heavy objects & 28.0 & 93.0 & $121(60.5 \%)$ \\
\hline Wear too tight underwear & 52.0 & 74.0 & $126(63.0 \%)$ \\
\hline Take injection in the affected arm & 23.0 & 36.0 & $59(29.5 \%)$ \\
\hline Wear accessories in the affected arm & 55.0 & 82.0 & $137(38.5 \%)$ \\
\hline Exposure to sunlight & 67.0 & 86.0 & $153(76.5 \%)$ \\
\hline Exposure to heat & 68.0 & 90.0 & $158(79.0 \%)$ \\
\hline Obesity & 86.0 & 83.0 & $169(84.5)$ \\
\hline
\end{tabular}


Figure (1): Mean Score of Pitting Edema for the Study and Control Group during the First Assessment, 6 Weeks, and 16 Weeks after Surgery
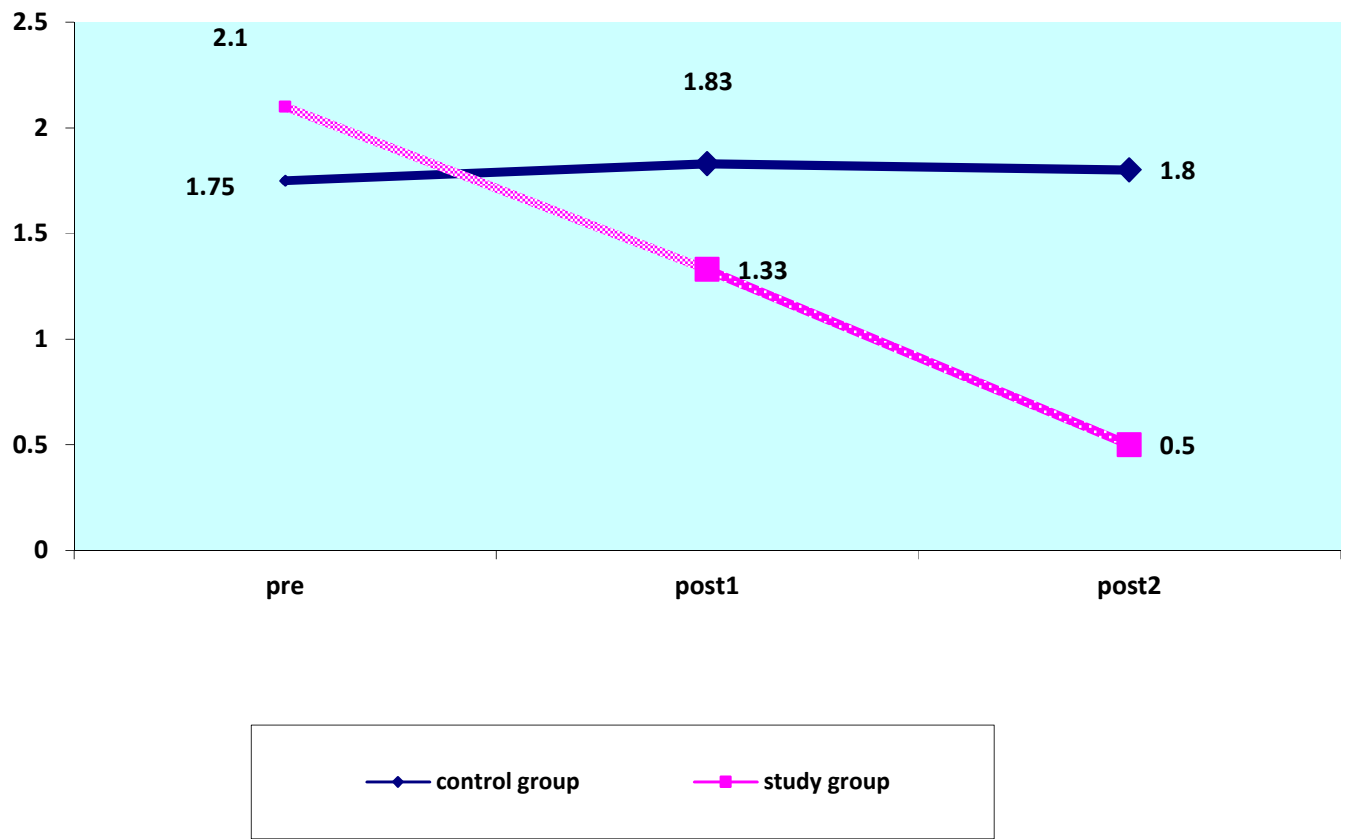
Table (6): Domains of Physical Activity as Reported by the Studied Subjects (n=200)

\begin{tabular}{|c|c|c|c|c|c|c|c|}
\hline \multirow{2}{*}{$\begin{array}{l}\text { Domains of } \\
\text { Physical Activity }\end{array}$} & \multicolumn{3}{|c|}{ Study Group $(n=100)$} & \multicolumn{3}{|c|}{ Control Group $(n=100)$} & P value \\
\hline & Low & Moderate & High & Low & \begin{tabular}{|c|c|}
$\begin{array}{c}\text { Mode } \\
\text { rate }\end{array}$ \\
\end{tabular} & High & \\
\hline \multicolumn{8}{|l|}{ Work Domain: } \\
\hline First assessment & 100.0 & 0.0 & 0.0 & 99.0 & 1.0 & 0.0 & $\mathrm{X}^{2}=1.1 \mathrm{p}>0.05$ \\
\hline Post 6 weeks & 82.0 & 18.0 & 0.0 & 86.0 & 9.0 & 5.0 & $\mathrm{X}^{2}=8.1 \mathrm{p}<0.05^{*}$ \\
\hline Post 16 weeks & 59.0 & 28.0 & 13.0 & 83.0 & 10.0 & 7.0 & $\mathrm{X}^{2}=14.3 \mathrm{p}<0.01^{*}$ \\
\hline \multicolumn{8}{|l|}{$\begin{array}{l}\text { Transportation } \\
\text { Domain: }\end{array}$} \\
\hline First assessment & 87.0 & 13.0 & 0.0 & 95.0 & 5.0 & 0.0 & $\mathrm{X}^{2}=3.9 \mathrm{p}<0.05^{*}$ \\
\hline Post 6 weeks & 64.0 & 36.0 & 0.0 & 77.0 & 23.0 & 0.0 & $\mathrm{X}^{2}=4.1 \mathrm{p}<0.05^{*}$ \\
\hline Post 16 weeks & 26.0 & 73.0 & 1.0 & 41.0 & 58.0 & 1.0 & $X^{2}=5.1 p>0.05$ \\
\hline \multicolumn{8}{|l|}{$\begin{array}{l}\text { Domestic } \\
\text { Domain: }\end{array}$} \\
\hline First assessment & 91.0 & 9.0 & 0.0 & 82.0 & 18.0 & 0.0 & $\mathrm{X}^{2}=3.4 \mathrm{p}>0.05$ \\
\hline Post 6 weeks & 83.5 & 16.5 & 0.0 & 95.1 & 4.9 & 0.0 & $\mathrm{X}^{2}=5.9 \mathrm{p}<0.05^{*}$ \\
\hline Post 16 weeks & 84.0 & 16.0 & 0.0 & 87.0 & 13.0 & 0.0 & $\mathrm{X}^{2}=0.4 \quad \mathrm{p}>0.05$ \\
\hline \multicolumn{8}{|l|}{$\begin{array}{l}\text { Total Pattern of } \\
\text { Physical activity: }\end{array}$} \\
\hline $\begin{array}{l}\text { First assessment } \\
\text { Post } 6 \text { weeks }\end{array}$ & 59.0 & 41.0 & 0.0 & 83.0 & 17.0 & 0.0 & $\mathrm{X}^{2}=13.9 \mathrm{p}<0.05^{*}$ \\
\hline Post 16 weeks & 77.0 & 23.0 & 0.0 & 70.0 & 29.0 & 1.0 & $\mathrm{X}^{2}=2.1 \mathrm{p}>0.05$ \\
\hline & 51.0 & 49.0 & 0.0 & 71.0 & 29.0 & 0.0 & $\mathrm{X}^{2}=8.4 \mathrm{p}<0.05^{*}$ \\
\hline \multicolumn{8}{|l|}{$\begin{array}{l}\text { Daily Hours in } \\
\text { Sedentary } \\
\text { Activity: }\end{array}$} \\
\hline First assessment & & $8.4 \pm 2.9 \mathrm{~h}$ & & & $9.1 \pm 2$. & & $\mathrm{t}=1.6 \quad \mathrm{p}>0.05$ \\
\hline Post 6 weeks & & $7.6 \pm 2.5 \mathrm{~h}$ & & & $8.64 \pm 2$ & & $\mathrm{t}=2.7 \quad \mathrm{p}<0.05^{*}$ \\
\hline Post 16 weeks & & $7.1 \pm 2.9 \mathrm{~h}$ & & & $8.4 \pm 2$ & & $\mathrm{t}=3.1 \quad \mathrm{P}<0.05^{*}$ \\
\hline
\end{tabular}


Table (7): Total Mean Score of Exercises Performance for the Study Group during First Assessment, Post 6 Weeks, and Post 16 Weeks

\begin{tabular}{|l|c|c|}
\hline Exercises & $\begin{array}{c}\text { Study Group } \\
(\mathbf{n}=\mathbf{1 0 0})\end{array}$ & P value \\
\hline Total Mean Score of Exercises Performance: & $18.57 \pm 4.9$ & \\
First Assessment & $17.37 \pm 5.01$ & $\mathrm{~F}=21.73$ \\
Post 6 Weeks & $17.67 \pm 4.9$ & $\mathrm{P}<0.001^{*}$ \\
\hline Post16 Weeks & \\
\hline
\end{tabular}

\section{Discussion:}

According to National Population-Based Cancer Registry Program, Egypt.)Breast cancer is the most common cancer today, about thirty-two new cases, are diagnosed per 100,000 women, (Ibrahim et al 2014). Lymphedema continues to be one of the main and most feared complications of breast cancer treatment (Martín, 2012). It occurs in an estimated $25 \%$ of patients who undergo treatment, although rates varying from $6 \%$ to $70 \%$ have been reported (Martín, 2012; McLaughlin, 2012). Therefore, the aim of the current study is to evaluate the effect of prophylactic physical activities on reducing lymphedema among women post-mastectomy.

During the current study, two hundred women are included in the study. The findings of the current study cover three main areas discussed within the following frame of references: First, patients' history and health-related data. Second, it was included the lymphedema characteristics, associated symptoms, stage, and risk factors. Third, this included the improvement in women physical activity and their practice of prophylactic exercises.

The present study result denotes that more than half of both groups are elderly women, This result is in accordance with National Cancer Institute (2017) revealed that the risk of breast cancer increases as individuals aged because the older are more likely to be exposed to changes in their cells . majority of the current studied sample were living in rural areas and illiterate. The findings mentioned comes in agreement with (Sisman et al., 2012) who stated that most of their women were from the rural area. The result of the current study might be due to a certain segment of the rural population with illiteracy, low incomes and their full dependence on free treatment by the government.

The majority of the current studied sample is not working. This comes in agreement with (Aybala, Kutun \& Cetin, 2014) who mentioned that BC was significantly more common in unemployed women than in those who were employed. Work might enhance individual health and maintain physical activity. While we considered unemployment, especially among elderly persons, may be negatively affected by individual activities.

The current study shows that most women in the sample have arthritis, hypertension, and diabetes that are common chronic problems among elderly individuals. Also, more than one-third of the participants have a family history of cancer, and most of them are obese. This result is in accordance with (Salam \& Luma, 2016) who reported that most of the participants had first degree relatives with breast cancer.

The results illustrated that during the first assessment, more than $80 \%$ of the sample complained from a stage 1 lymphedema after surgery. However, there is a significant reduction in these percentages among the study group after the implementation of the prophylactic physical activities. This finding was observed by (Kaviani et al., 2013) who revealed that most of the women had stage I lymphedema during the first few days after surgery, due to the surgical removal of lymphonod. Later, lymphedema decreased after months.

The current study represents that, there is a statistically significant difference between the control and study group regarding the lymphedema time during the first assessment, post six weeks, and post sixteen weeks after surgery. Most women develop edema in the first assessment and some of the women continue edema for six weeks, and after sixteen weeks of post evaluation. This might be related to surgery. This in agreement with (Ardıç \& Yorgancioğlu, 2006) who explained that mild lymphedema developed within a few days after surgery and 
moderate lymphedema can occur about four to six weeks after surgery but sever lymphedema develop eighteen to twenty-four months. Also, (Dayes et al., 2013) who documented that temporary lymphedema lasts fewer than six months and the probability of lymphedema progression increases according to the variety of applied surgery.

The present study finding reveals that significant improvement among study group compared with control group regarding lymphedema initial symptoms such as arm heaviness, inability to move the arm, discomfort, axillary edema, and total pain after mastectomy post sixteen weeks follow-up. This is might be related to regular exercises. This result is in agreement with (Taghian et al., 2014) who emphasized that there was an improvement in physical symptoms associated with lymphedema including the inability to move the arm, fatigue, and pain in the arm. On another hand, this finding comes in accordance with (Martín et al., 2011) and (Uzkeser, 2012) who documented that the practice of physical exercises and knowledge acquired from the attendance of the class education decreased the symptoms associated with the appearance of lymphedema

The existing study notes that some of the women with risk factors are more likely to be at risk for lymphedema than others. Also, noted that the proportion of women who are exposed to lymphedema in the study group is less than in control group related to risk factors, this might be as a result of awareness of risk factors and trying to avoid them as much as possible.

Present study finding shows that more than half of the sample who lift heavy objects is a risk for lymphedema. This result is in accordance with (Cemal et al., 2011) who said lifting heavy objects would increase the risk for lymphedema. These results disagreed with (Schmitz et al., 2010) who reported that lifting heavy weight did not increase the risk of lymphedema. Nearly half of the study sample is age more than sixty-five. This finding is similar to (Mak et al., 2009) and (Mattias et al., 2017) who documented that occurrence of lymphedema significantly increases with age, as demonstrated in the present study. Finally, a minority of the study sample started treatment with radiotherapy, which is considered one of the risk factors. This increased the risk of occurrence lymphedema. This might be related to most of the samples start radiotherapy after more than 6 months except some of them start early. This result is Similar to (Bevilacqua et al., 2012) and (Ozcinar et al., 2012) who documented that radiation is a risk factor for lymphedema.

The present finding revealed that there is a significant reduction in the mean score of pitting edema for the intervention during the first assessment, six weeks, and sixteen weeks after post-intervention, while the mean score of pitting edema for the control group is still high. Also, about half of the intervention group compared to a minority of the control group has a moderate level of physical activity during the post-test. This indicates an increase in the level of a total pattern of physical activity for the intervention group with statistically significant differences between the two groups during the post-test. So, the intervention group has better physical activities than the control group. This result is in the same line to (Belmonte, 2012) and (Bergmann et al., 2014) who said that the early physical activity during the postoperative period they may decrease the risk of lymphedema development.

The preventive measures of lymphedema are implemented early during the postoperative period. Also, another study stated that increased knowledge helped to prevent or minimize lymphedema. Many participants mentioned that they believed that their knowledge gained from the educational class helped them prevent the development of lymphedema or decrease any swelling that may develop (Jeffs \& Purushotham, 2016).

The result of the current study documented that the total mean score of exercises performance improved for the intervention group after the six weeks, and post for sixteen weeks.

These results were in accordance with (Naghibi \& Varshoie, 2018) who concluded that exercise training acted as a treatment method to control lymphedema in breast cancer survivors. The education and practice should be provided by the nurses about the prophylactic exercises to prevent lymphedema development (Sisman et al., 2012). Besides, the prophylactic activities should begin immediately after mastectomy, at a hospital ward (Rasu et al., 2011). Finally, the prophylactic physical activities are effective to reduce lymphedema among women after mastectomy.

\section{Conclusion:}

The results of this study concluded that prophylactic physical activities reduced the lymphedema associated symptoms among the intervention group. Also, women who implemented the prophylactic physical activities are 
more likely to increase their level of physical activity than before the intervention. Added to that, the intervention group has a better level of physical activities than the control group. In addition to increasing awareness of the women about risk factors and the importance of following educational intervention help to reduce the lymphedema.

\section{Recommendations:}

1. Prophylactic physical activities are essential measures after mastectomy to reduce lymphedema development.

2. The medical-surgical and geriatric nurses should continue their nursing instructions for women about how to avoid the risk factors that can increase lymphedema.

3. We endorse a unified effort among nurses and health providers caring for breast cancer women to work together to arrive at a consensus regarding these dilemmas

4. Established and conducted a training program on a regular basis for nurses who are in contact with the post-mastectomy women.

\section{References:}

Abdel Dayem, O. T., Saeid, M. M., Ismail, O. M., El Badrawy, A. M., \& Abdel Ghaffar, N. A. (2014). Ultrasoundguided stellate ganglion block in postmastectomy pain syndrome: a comparison of ketamine versus morphine as an adjuvant to bupivacaine. Journal of Anesthesiology, 2014.

Albain, K. S., Barlow, W. E., Shak, S., Hortobagyi, G. N., Livingston, R. B., Yeh, I. T., \& Sledge, G. W. (2010). Prognostic and predictive value of the 21-gene recurrence score assay in postmenopausal women with nodepositive, estrogen-receptor-positive breast cancer on chemotherapy: a retrospective analysis of a randomized trial. The lancet oncology, 11(1), 55-65.

Ibrahim, A. S., Khaled, H. M., Mikhail, N. N., Baraka, H., \& Kamel, H. (2014). Cancer incidence in Egypt: results of the national population-based cancer registry program. Journal of cancer epidemiology, 2014.

Angahar LT, (2017). An Overview of Breast Cancer Epidemiology, Risk Factors, Pathophysiology, and Cancer Risks Reduction. MOJ Biology and Medicine

Australia \& New Zealand Society of Vascular Surgeons.2018. Lymphoedema. Available at http://www.anzsvs.org.au/patient-information/lymphoedema/. Accessed on March 2018.

Ayhan-Ardiç, F. F., \& Yorgancioğlu, Z. R. (2006). BREAST CANCER AND REHABILITATION 1SSUES. Turkiye Klinikleri Journal of Internal Medical Sciences Physical Medicine and Rehabilitation, 2(10), 39. Aybala, A. A., Kutun, S., \& Cetin, A. (2014). Lymphoedema after mastectomy for breast cancer: Importance of supportive care. South African Journal of Surgery, 52(2), 41-44.

Belmonte, R., Tejero, M., Ferrer, M., Muniesa, J. M., Duarte, E., Cunillera, O., \& Escalada, F. (2012). Efficacy of low-frequency low-intensity electrotherapy in the treatment of breast cancer-related lymphoedema: a cross-over randomized trial. Clinical Rehabilitation, 26(7), 607-618.

Bergmann, A., Ferreira, M. D. C. L., De Aguiar, S. S., de Almeida Dias, R., de Souza Abrahao, K., Paltrinieri, E. M., \& de Andrade, M. C. (2014). Physiotherapy in upper limb lymphedema after breast cancer treatment: a randomized study. Lymphology, 47(2), 82-91.

Bevilacqua, J. L. B., Kattan, M. W., Changhong, Y., Koifman, S., Mattos, I. E., Koifman, R. J., \& Bergmann, A. (2012). Nomograms for predicting the risk of arm lymphedema after axillary dissection in breast cancer. Annals of surgical oncology, 19(8), 2580-2589.

Brodovicz, K., McNaughton, K., Uemura, N., Meininger, G, Girman, C., \& Yale, S. (2009). Reliability and feasibility of methods to quantitatively assess peripheral edema. Clinical Medicine \& Research, 7(1/2) P 21-31. Retrieved March 2010, from http://www.EBSCOhost.com 
Bevilacqua, M. W. Kattan, Y. Changhong et al., 2012."Nomograms for predicting the risk of arm lymphedema after axillary dissection in breast cancer," Annals of Surgical Oncology, vol. 19, no. 8, pp. 2580-2589, 2012.

Booth, M. (2000). Assessment of physical activity: an international perspective. Research quarterly for exercise and sport, 71(sup2), 114-120.

Cemal, Y., Pusic, A., \& Mehrara, B. J. (2011). Preventative measures for lymphedema: separating fact from fiction. Journal of the American College of Surgeons, 213(4), 543-551.

Chan, E. (2009). Risk factors for the initiation and aggravation of lymphoedema after axillary lymph node dissection for breast cancer. Hong Kong Med J, 15(3 Supplement 4), 9.

Cheifetz, O., \& Haley, L. (2010). Management of secondary lymphedema related to breast cancer. Canadian Family Physician, 56(12), 1277-1284.

Clark, B., Sitzia, J., \& Harlow, W. (2005). Incidence and risk of arm edema following treatment for breast cancer: a three-year follow-up study. Qjm, 98(5), 343-348.

Craig, C. L., Marshall, A. L., Sjorstrom, M., Bauman, A. E., Booth, M. L., Ainsworth, B. E., ... \& Oja, P. (2003). International physical activity questionnaire: 12-country reliability and validity. Medicine and science in sports and exercise, 35(8), 1381-1395.

Dayes, I. S., Whelan, T. J., Julian, J. A., Parpia, S., Pritchard, K. I., D'Souza, D. P., ... \& Manchul, L. (2013). Randomized trial of decongestive lymphatic therapy for the treatment of lymphedema in women with breast cancer. Journal of clinical oncology, 31(30), 3758-3763.

DiSipio, T., Rye, S., Newman, B., \& Hayes, S. (2013). The incidence of unilateral arm lymphoedema after breast cancer: a systematic review and meta-analysis. The lancet oncology, 14(6), 500-515.

Dominick, S. A., Madlensky, L., Natarajan, L., \& Pierce, J. P. (2013). Risk factors associated with breast cancerrelated lymphedema in the WHEL Study. Journal of Cancer Survivorship, 7(1), 115-123.

Dziura, I., \& Grądalski, T. (2008). Knowledge of etiological factors of lymphedema and adherence to prophylactic recommendations among mastectomized patients. Rehabil Med, 4, 23-7.

Elkhodary, T. R., Ebrahim, M. A., Hatata, E. E., \& Niazy, N. A. (2014). Prognostic value of lymph node ratio in node-positive breast cancer in Egyptian patients. Journal of the Egyptian National Cancer Institute, 26(1), 31-35.

EL-SAYED, N. O., \& ALI, Z. H. (2011). Effect of counseling intervention post mastectomy for women undergoing adjuvant chemotherapy on their quality of life. The Medical Journal of Cairo University, 79(2).

Eur J Gen Med .2012; 9(2):130-134Dr. Hulya Uzkeser, State Hospital, Department of Physical Medicine and Rehabilitation

Ferlay J., Soerjomataram I., Dikshit R., et al., 2012. Cancer incidence and mortality worldwide: Sources, methods and major patterns in Globocan 2012. Int. J. Cancer. 136: E359-86, 2015

Golshan M, Smith B. 2006. Prevention and management of arm lymphedema in the patient with breast cancer. J Support Oncol. 2006 Sep;4(8):381-6.

Helyer, L. K., Varnic, M., Le, L. W., Leong, W., \& McCready, D. (2010). Obesity is a risk factor for developing postoperative lymphedema in breast cancer patients. The breast journal, 16(1), 48-54.

Helyer, L. K., Varnic, M., Le, L. W., Leong, W., \& McCready, D. (2010). Obesity is a risk factor for developing postoperative lymphedema in breast cancer patients. The breast journal, 16(1), 48-54. 
Hoffner, M., Bagheri, S., Hansson, E., Manjer, J., Troëng, T., \& Brorson, H. (2017). SF-36 shows increased the quality of life following complete reduction of postmastectomy lymphedema with liposuction. Lymphatic research and biology, 15(1), 87-98.

Huang, H., Zhou, J., \& Zeng, Q. (2012). Secondary lymphoedema after breast cancer surgery: a survival analysis. International journal of nursing practice, 18(6), 589-594.

Huang, T. W., Tseng, S. H., Lin, C. C., Bai, C. H., Chen, C. S., Hung, C. S., ... \& Tam, K. W. (2013). Effects of manual lymphatic drainage on breast cancer-related lymphedema: a systematic review and meta-analysis of randomized controlled trials. World journal of surgical oncology, 11(1), 15. zkeser, H. (2012). Assessment of postmastectomy lymphedema and current treatment approaches. Eur J Gen Med, 9(2), 130-34.

IARC Working Group on the Evaluation of Carcinogenic Risks to Humans, World Health Organization, \& International Agency for Research on Cancer. (2007). Combined estrogen-progestogen contraceptives and combined estrogen-progestogen menopausal therapy (Vol. 91). World Health Organization.

International Society of Lymphology (ISL). 2013. The diagnosis and treatment of peripheral lymphedema: 2013 Consensus Document of the International Society of Lymphology. Lymphology. 2013 Mar; 46(1):1-11.

International Society of Lymphology. The diagnosis and treatment of peripheral lymphedema: 2013 Consensus Document of the International Society of Lymphology. Lymphology. 2013;46(1):1-11.

International Society of Lymphology. The Diagnosis and Treatment of Peripheral Lymphedema: 2016 Consensus Document of the International Society of Lymphology. Journal of. Lymphology 49 (2016) 170-184.

ISL, I. (2009). The diagnosis and treatment of peripheral lymphedema: 2013 consensus document of the International Society of Lymphology. Lymphology, 46(1), 1-11.

Jeffs, E., \& Purushotham, A. (2016). The prevalence of lymphoedema in women who attended an information and exercise class to reduce the risk of breast cancer-related upper limb lymphoedema. SpringerPlus, 5(1), 21.

Kayıran O., Cruz CD., Tane K., and Soran A.2017. Lymphedema: From diagnosis to treatment. Turk J Surg. 2017; 33(2): 51-57.

Kristensen, T. B., Knutsson, M. L., Wehland, M., Laursen, B. E., Grimm, D., Warnke, E., \& Magnusson, N. E. (2014). Anti-vascular endothelial growth factor therapy in breast cancer. International journal of molecular sciences, 15(12), 23024-23041.

Lee, B. B. B. (2013). Diagnosis and Treatment of Primary Lymphedema Consensus Document of the International Union of Phlebology (IUP)- (Doctoral dissertation, Department of Surgery, University of São Paulo).

Lee, J. H., Shin, B. W., Jeong, H. J., Kim, G. C., Kim, D. K., \& Sim, Y. J. (2013). Ultrasonographic evaluation of therapeutic effects of complex decongestive therapy in breast cancer-related lymphedema. Annals of rehabilitation medicine, 37(5), 683-689.

Linda T. Miller, PT, DPT, CLT Reducing Lymphedema Risk: Before Surgery March 26, 2014 at 11:11 AM)lymphoedema after cancer treatment: Early detection and risk reduction. A guide for health professionals. www.cancercontrol.hse.ie.

Mak SS, Yeo W, Lee YM, et al. Risk factors for the initiation and aggravation of lymphoedema after axillary lymph node dissection for breast cancer. Hong Kong Med J 2009;15(4):8-12.

[http://dx.doi.org/10.1097/nnr.0b013e31818c3de2] 
Malin L. T. Knutsson, $1, \uparrow$ Markus Wehland,2 Britt Elmedal Laursen,3 Daniela Grimm,1,*Elisabeth Warnke,2 and Nils E. Magnusson 2014) Anti-Vascular Endothelial Growth Factor Therapy in Breast Cancer. nternational Journal of Molecular Sciences — Open Access Journal,2014 Dec; 15(12): 23024-23041.

Martín, M. L., Hernández, M. A., Avendaño, C., Rodríguez, F., \& Martínez, H. (2011). Manual lymphatic drainage therapy in patients with breast cancer related lymphoedema. BMC cancer, 11(1), 94.

Mattias Hoffner, MD, Shirin Bagheri, MD, Emma Hansson, MD, Jonas Manjer, MD, Thomas Troe “ng, MD, \& $\mathrm{Ha}{ }^{\circ}$ kan Brorson, MD, PhD1 SF-36 Shows Increased Quality of Life Following Complete Reduction of Postmastectomy Lymphedema with Liposuction. LYMPHATIC RESEARCH AND BIOLOGY, Volume 15, Number 1, 2017. Mary Ann Liebert, Inc. DOI: 10.1089/1rb.2016.0035.

Mclaughlin, S. A. (2012). Lymphedema: separating fact from fiction. Cancer, 26(3).

Mehrara, B., \& Bruera, E. Patient education: Lymphedema after cancer surgery (Beyond the Basics). Available at https://www.uptodate.com/contents/lymphedema-after-cancer-surgery-beyond-the-basics\#H1. Accessed at March 2018

Melzack, R. (1987). The short-form McGill pain questionnaire. Pain, 30(2), 191-197.

Modaral B, Lyons TA. Lymphoedema. available: clinical key.com at MOH consortium. Shahid Beheshti university of Medical Sciences;2016.

Mohler III ER, Mehrara B, Eidt JF, Berman RS, Mills Sr JL, Collins KA, et Moseley AL, - - Piller NB, Carati CJ. The effect of gentle arm exercise and deep breathing on secondary arm lymphedema. Lymphology. 2005 Sep; 38(3):136-45.

Moseley, A. L., Piller, N. B., \& Carati, C. J. (2005). The effect of gentle arm exercise and deep breathing on secondary arm lymphoedema.

Naghibi, S., \& Tabrizi, F. V. (2018). Exercise Training and Breast Cancer-Related Lymphedema: A Systematic Review. Cancer [MeSH Major Topic], 2, 776.

Naghibi, S., \& Tabrizi, F. V. 2018. Exercise Training and Breast Cancer-Related Lymphedema: A Systematic Review. Cancer [MeSH Major Topic], 2, 776.

National Cancer Control Programme. 2015.Prevention of clinical lymphoedema after cancer treatment: Early detection and risk reduction. A guide for health professionals. www.cancercontrol.hse.ie.

.National Cancer Institute. Cancer Stat Facts: Female Breast Cancer 2017. Available at https://seer.cancer.gov/statfacts/html/breast.html

National Cancer Registry 2010,http://onkologia.org.pl/nowotwory-piersikobiet/, Accessed on February 2nd,2014.(Polish)

National Cancer Registry Program of Egypt. Reports and Statistics: Aswan, Damietta \& ElMinia;2012.Available at: http://www.cancerregistry.gov.eg/reports.aspx. Accessed on 05.09.12

National Lymphedema Network (2012.)Lymphedema Risk Reduction Practices

Noguchi M. Axillary reverse mapping for breast cancer. Breast Cancer Res Treat 2010;19:529-35.

Norman, S. A., Localio, A. R., Potashnik, S. L., Torpey, H. A. S., Kallan, M. J., Weber, A. L., \& Solin, L. J. (2009). Lymphedema in breast cancer survivors: incidence, degree, time course, treatment, and symptoms. Journal of Clinical Oncology, 27(3), 390. 
Polit D. F. \& Beck CT. (2004). Nursing research. Principles and methods. CHAPTER 8. Designs for Nursing Research. 7 th ed. 185-186.

Ridner SH, Dietrich MS, Stewart BR, Armer JM. Body mass index and breast cancer-related lymphedema. Support Care Cancer . 2011;19(6):853-857.

Runowicz, C. D., Leach, C. R., Henry, N. L., Henry, K. S., Mackey, H. T., Cowens-Alvarado, R. L., ... \& Hurria, A. (2016). American cancer society/American society of clinical oncology breast cancer survivorship care guideline. CA: a cancer journal for clinicians, 66(1), 43-73.

Safwat Y, Shaalan M, Mokhtar M, Hamood M.2017. Risk factors of upper-arm lymphedema after breast cancer treatment. Journal of current medical research and pract

Salam Hussein Ewaid ,Luma Hussein Ali Al-Azzawi. 2016. Breast cancer risk assessment by Gail Model in women of Baghdad,Available online 22 September 2016, Alexandria Journal of Medicine(2017),53;41-47.

Schmitz KH, Ahmed RL, Troxel AB, Cheville A, Lewis-Grant L, Smith R, et al. Weight lifting for women at risk for breast cancer-related lymphedema: a randomized trial. JAMA. 2010; 304(24):2699-705. doi:10.1001/jama.2010.1837. [PubMed: 21148134].

Senn, B., Kobleder, A., Raphaelis, S., Mueller, M. D., Kammermann, B., White, K., \& Eicher, M. (2015). Prevention and reduction of complications in women with vulvar Cancer: development of an algorithm for safer multidisciplinary care. Journal of Cancer Therapy, 6(10), 821.

Shaw C, Mortimer P, Judd PA. A randomized controlled trial of weight reduction as a treatment for breast cancer-related lymphedema. Cancer. 2007 Oct 15;110(8):1868-74

Siegel R, DeSantis C, Virgo K, Stein K, Mariotto A, Smith T, Cooper D, Gansler T, Lerro C, Fedewa S, Lin C, Leach C, Cannady RS, Cho H, Scoppa S, Hachey M, Kirch R, Jemal A, Ward E. Cancer treatment and survivorship statistics, 2012. CA Cancer J Clin. 2012;62:220-241. [PubMed SIEGEL R., MA J., ZOU Z. and JEMAL A.: Cancer statistics. CA Cancer J. Clin., 64: 9-29, 2014.

Sisman H, B. Sahin2, B.B. Duman2, G. Tanriverdi.2012. Nurse-assisted education and exercise decrease the prevalence and morbidity of lymphedema following breast cancer surgery. Journal of B.U.O.N (journal of the Balkan Union of Oncology) • October 2012. 17: 565-569,

Sun.,W,chou.,CP.,Stacy,A.W., Unger,j., and Gallaher,P,SAS and SPSS macros to calculate standandized cronbach's alpha using the upper bound of the phi coefficient for dichotomous items .Behavior Research Methods.2007,39(1),71-81.

Taghian N. R. , C. L. Miller, L. S. Jammallo, J. O’Toole, and M. N. Skolny, "Lymphedema following breast cancer treatment and impact on quality of life: a review," Critical Reviews in Oncology/Hematology, vol. 92, no. 3, pp. 227-234, 2014.

Tiwari P, Coriddi M, Salani R, Povoski SP. Breast and gynaecologic cancer-related extremity lymphedema: a review of diagnostic modalities and management options.World J Surgical Oncology. 2013;11:237.

Torre LA1, Bray F, Siegel RL, Ferlay J, Lortet-Tieulent J, Jemal A. 2015, Global cancer statistics, 2012.( 2015 Mar;65(2):87-108.doi: 10.3322/caac.21262. Epub 2015 Feb 4).

Variawa ML. The prevalence of chronic postmastectomy pain syndrome in female breast cancer survivors.Southern African Journal of Anaesthesia and Analgesia.2016;22(4):108-113. doi:10.1080/22201181.2016.1191214. 
Voichita Bar, Cheville, A., Solin, L. J., Dutta, P., Both, S., \& Harris, E. E. (2010). Time course of mild arm lymphedema after breast conservation treatment for early-stage breast cancer. International Journal of Radiation Oncology* Biology* Physics, 76(1), 85-90.

WHO. Media Centre: Cancer-Fact Sheet No.297;2015.<http:/www.who.int/mediacentre/factsheets/fs297/en/

World Cancer Research Fund / American Institute for Cancer Research. Food, Nutrition, Physical Activity, and the Prevention of Cancer: a Global Perspective. Washington DC: AICR, 2007.

World Health Organization. "BMI Classification". Global Database on Body Mass Index. ( 2004): Last update: 26/12/2017. Available at http://apps.who.int/bmi/index.jsp?introPage=intro_3.html. Accessed at 26 December 2017

World Health Organization; (2018) http://www.who.int/ar/news-room/fact-sheets/detail/cancer www.vascular.co.nz/lymphoedema.htm. Accessed 31st July 2014. 